\title{
PENGOLAHAN LIMBAH CAIR TAHU MENGGUNAKAN BIOREAKTOR ANAEROB SATU TAHAP DAN DUA TAHAP SECARA BATCH
}

\section{TOFU LIQUID WASTE TREATMENT USING ANAEROB BATCH BIOREACTOR ONE STAGE AND TWO STAGE}

\author{
Florence T.N. Silalahi*, Halimatuddahliana, dan Amir Husin \\ Program Studi Teknik Lingkungan, Fakultas Teknik, Universitas Sumatera Utara \\ Jl. Almamater, Kampus USU, Padang Bulan, Medan 20155, Indonesia \\ *E-mail: florencesilalahi15@gmail.com
}

\begin{abstract}
Abstrak
Penelitian ini bertujuan untuk mempelajari pengaruh pengolahan anaerob satu tahap dan dua tahap terhadap kinerja bioreaktor dalam pengolahan limbah cair tahu. Penelitian ini dimulai dengan aklimatisasi yaitu proses adaptasi mikroorganisme yang berasal dari kotoran sapi dengan limbah cair tahu. Aklimatisasi dilakukan dalam suasana asam ( $\mathrm{pH} 5,5)$ dan dalam suasana netral ( $\mathrm{pH} 7)$. Kemudian dilanjutkan dengan pengoperasian bioreaktor secara batch selama 40 hari untuk pengolahan anaerob satu tahap ( $\mathrm{pH} 7)$, sementara untuk tahap pertama pengolahan anaerob dua tahap $(\mathrm{pH} 5,5)$ berlangsung dua hari dan dilanjutkan dengan tahap kedua pengolahan anaerob dua tahap $(\mathrm{pH} 7)$ yang berlangsung 38 hari. Hasil yang diperoleh adalah efisiensi penyisihan COD 76,6\% untuk anaerob satu tahap dan $83,05 \%$ untuk anaerob dua tahap. Sementara konsentrasi VFA pada tahap pertama anaerob dua tahap meningkat sebesar 33\% dari anaerob satu tahap. Yield biogas anaerob satu tahap sebesar $0,24 \mathrm{~L} / \mathrm{g}$ $\mathrm{COD}_{\text {terkonversi dan }} 0,27 \mathrm{~L} / \mathrm{g}$ COD terkonversi untuk anaerob dua tahap.
\end{abstract}

Kata kunci: bioreaktor anaerob satu tahap, bioreaktor anaerob dua tahap, limbah cair tahu, $\mathrm{pH}$.

\begin{abstract}
This research aimed to study the effect of one stage and two stage anaerobic fermentation on the performance of bioreactors in tofu liquid waste treatment. This research started with acclimatization that is adaptation process of microorganism derived from cow dung with tofu liquid waste. Acclimatization is carried out in acid condition ( $p H 5.5)$ and in neutral condition ( $p H$ 7). This is followed by a batch bioreactor operation for 40 days for one stage anaerobic fermentation ( $p H 7)$, while for the first stage of the two stage anaerobic fermentation ( $\mathrm{pH}$ 5.5) lasted two days and proceeds with the second stage of the two stage anaerobic fermentation ( $p H 7)$ lasts 38 days The results obtained were COD removal efficiency of $76.6 \%$ for one stage anaerobic and $83.05 \%$ for two stage anaerobic. While the VFA concentration in the first stage of the two stage anaerobic increased by $33 \%$ of the onestage anaerobic VFA concentration. One-stage anaerobic biogas yield of $0.24 \mathrm{~L} / \mathrm{g} C O D_{\text {converted }}$ and 0.27 $L / g C O D_{\text {converted }}$ for to two stage anaerobic.
\end{abstract}

Keywords: one stage anaerobic bioreaktor, two stage anaerobic bioreaktor, tofu liquid waste, $p H$.

\section{Pendahuluan}

Saat ini industri tahu berkembang pesat diberbagai daerah, dan sebagian besar tidak dilengkapi dengan unit pengolahan limbah. Limbah cair tahu mengandung bahan organik yang tinggi. Limbah yang mengandung bahan organik tinggi, apabila dibuang langsung ke sungai dapat mengakibatkan terganggunya kualitas air dan menurunkan daya dukung lingkungan perairan.

Pengolahan limbah cair yang sesuai untuk mengatasi kandungan bahan organik yang tinggi adalah dengan pengolahan secara anaerobik. Penguraian senyawa organik secara anaerob dapat dibagi menjadi dua, yakni penguraian satu tahap dan dua tahap [11].

Dalam studi ini dilakukan pengolahan limbah cair tahu dengan proses anaerob satu tahap dan dua tahap, yang bertujuan untuk mempelajari pengaruh dari pengolahan anaerob satu tahap dan dua tahap terhadap penurunan bahan organik yang ditinjau dari parameter Chemical Oxygen Demand (COD), pertumbuhan bakteri yang dipantau dari parameter Volatile Suspendeed Solid (VSS), produksi Volatile Fatty Acid (VFA), dan produksi biogas.

Teori

Proses anaerobik adalah proses proses biologi yang memanfaatkan mikroorganisme dalam mendegradasi bahan organik dengan kondisi tidak dapat atau sangat sedikit oksigen terlarut [5]. Proses penguraian anaerobik dapat digolongkan menjadi empat tahapan reaksi, yaitu tahap hidrolisis, tahap pembentukan asam (asidogenesis), tahap pembentukan asetat (asetogenesis), dan tahap pembentukan gas metana (metanogenesis). Hidrolisis adalah proses dimana aktivitas kelompok bakteri hidrolitik menguraikan bahan organik kompleks. 
Asidogenesis merupakan proses perombakan monomer dan oligomer menjadi asam asetat, $\mathrm{CO}_{2}$, asam lemak rantai pendek, serta alkohol. Asetogenesis menghasilkan asam asetat, $\mathrm{CO}_{2}$, dan $\mathrm{H}_{2}$. Metanogenesis merupakan tahap akhir dari keseluruhan konversi zat organik menjadi $\mathrm{CH}_{4}$ dan $\mathrm{CO}_{2}$ [3].

Secara garis besar penguraian senyawa organik secara anaerob dapat dibagi menjadi dua, yakni anaerob satu tahap dan dua tahap. Pada anaerob satu tahap, proses hidrolisis, asidogenesis, asetogenesis, dan metanogenesis dilakukan dalam satu reaktor. Hal ini dapat menyebabkan proses hidrolisa kurang efektif karena kondisi operasi pertumbuhan antara mikroorganisme pembentukan asam (hidrolisis, asidogenesis, dan asetogenesis) dan pembentukan metana (metanogenesis) berbeda [11]. Sementara anaerob dua tahap, proses hidrolisis, asidogenesis, asetogenesis, dan metanogenesis dilakukan dalam suatu reaktor sistem dua tahap. Proses hidrolisis, asidogenesis, dan asetogenesis terjadi pada tahap pertama, sedangkan proses metanogenesis terjadi pada tahap kedua [2].

Keuntungan yang diperoleh dari sistem dua tahap ini yaitu, meningkatkan kandungan gas metan, mampu menguraikan senyawa organik dalam jumlah yang lebih besar, lebih stabil, dan lebih cepat [7].

Secara umum berdasarkan aliran bahan baku dalam pengolahan anaerobik dibagi menjadi tiga yaitu batch (curah), semi kontinyu, kontinyu. Dalam penelitian ini jenis aliran bahan baku yang digunakan adalah batch. Pada sistem batch, reaktor diisi dengan bahan baku (air limbah) dengan penambahan biakan mikroba sebanyak sekali saja. Reaktor tersebut harus berada dalam keadaan tertutup dan diberikan waktu retensi dengan periode tertentu, bila telah melewati waktu retensi maka reaktor dibuka, air limbah dibuang, dan diisi kembali dengan bahan baku [12].

\section{Metodologi Penelitian \\ Persiapan alat dan bahan}

Limbah cair tahu diperoleh dari industri tahu di Kecamatan Medan Polonia, sementara kotoran sapi yang digunakan sebagai inokulum diperoleh dari peternakan sapi di daerah Sei Mencirim, Medan Sunggal. Penelitian ini menggunakan bioreaktor anaerob satu tahap dan dua tahap yang masing-masing terbuat dari bahan plastik dengan volume efektif $7 \mathrm{~L}$ yang dilengkapi outlet pengambilan sampel dan perlengkapan water displacement. Desain bioreaktor lebih jelasnya dapat dilihat pada Gambar 1.

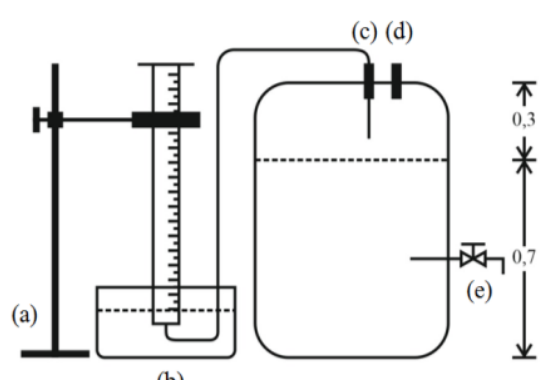

Gambar 1. Desain Reaktor

Keterangan gambar:

(a) Statif; (b) Water Displacement; (c) Inlet; (d) Inlet Gas Nitrogen; (e) Outlet

\begin{abstract}
Aklimatisasi
Kotoran sapi diencerkan dengan air (1:1) dan disaring untuk menghilangkan partikel-partikel kasar. Cairan yang lolos saringan diaklimatisasi dengan limbah cair tahu dengan perbandingan 1:4 dalam kondisi anaerob secara batch. Aklimatisasi dilakukan dalam dua suasana $\mathrm{pH}$, yang pertama suasana $\mathrm{pH}$ asam yaitu 5,5 untuk inokulum tahap asidogenesis, dan $\mathrm{pH}$ netral yaitu 7 untuk inokulum tahap. Kemudian diinkubasi sampai proses tersebut menghasilkan biogas. Pengkondisian $\mathrm{pH}$ dilakukan dengan menambahkan larutan $\mathrm{NaOH}$ [10].
\end{abstract}

\section{Pengoperasian Bioreaktor}

a. Bioreaktor Anaerob Satu Tahap (R1)

Disediakan limbah cair tahu sebanyak 5,6 liter dan kotoran sapi yang telah diaklimatisasi dalam suasana $\mathrm{pH}$ netral yaitu 7 sebanyak 1,4 liter, dihomogenkan dan dilakukan pengaturan $\mathrm{pH}$ agar tetap netral (pH 7). Dimasukkan campuran limbah cair tahu dengan kotoran sapi ke dalam bioreaktor anaerob, dialirkan gas nitrogen, kemudian tutup rapat bioreaktor. Setiap 3 hari selama 40 hari dilakukan pengamatan $\mathrm{pH}$, laju volumetrik gas dan pengambilan sampel untuk pengukuran COD, VSS, VFA.

b. Bioreaktor Anaerob Dua Tahap (R2)

Disediakan limbah cair tahu sebanyak 5,6 liter dan kotoran sapi yang telah diaklimatisasi dalam suasana asam $(\mathrm{pH} \mathrm{5,5)}$ sebanyak 1,4 liter, dihomogenkan dan dilakukan pengaturan $\mathrm{pH}$ pada suasana asam ( $\mathrm{pH}$ 5,5). Dimasukkan campuran limbah cair tahu dengan kotoran sapi ke dalam bioreaktor anaerob, dialirkan gas nitrogen, kemudian tutup rapat bioreaktor. Setelah 48 jam dari tahap pertama (R2-1) lalu kembali ditambahkan inokulum. dan ditambahkan $\mathrm{NaOH}$ hingga nilai $\mathrm{pH}$ menjadi 7 sebelum akhirnya dimasukkan ke dalam bioreaktor 
tahap kedua (R2-2). Dilakukan pengamatan $\mathrm{pH}$, laju volumetrik gas dan pengambilan sampel untuk pengukuran COD, VSS, VFA setiap 12 jam pada tahap pertama dan setiap 3 hari pada tahap kedua.

Pada penelitian ini pengukuran $\mathrm{pH}$ dilakukan dengan menggunakan $\mathrm{pH}$ meter, analisa COD dilakukan dengan metode titimetri, pertumbuhan bakteri diamati melalui parameter VSS yang diukur dengan metode gravimetri, analisa VFA dilakukan dengan metode destilasi uap, dan pengukuran biogas dilakukan dengan menggunakan metode Water Displacement yaitu dengan cara mengamati volume air yang berkurang pada gelas ukur terbalik pada rangkaian water displacement.

\section{Hasil dan Pembahasan \\ Karakteristik Limbah Cair}

Pada awal penelitian dilakukan analisis limbah cair tahu untuk mengetahui karakteristik limbah cair tahu yang akan diolah. Karakteristik limbah cair industri tahu dapat dilihat pada Tabel 1.

Tabel 1. Karakteristik Limbah Cair Tahu

\begin{tabular}{|c|c|c|}
\hline Parameter & Satuan & $\begin{array}{c}\text { Hasil } \\
\text { Analisa }\end{array}$ \\
\hline COD & $\mathrm{mg} / \mathrm{l}$ & 2489 \\
\hline TSS & $\mathrm{mg} / \mathrm{l}$ & 760 \\
\hline $\mathrm{pH}$ & - & 3,9 \\
\hline
\end{tabular}

Dari hasil analisa karakteristik awal pada tabel 1 dapat diketahui limbah cair tahu memiliki nilai COD lebih dari $1000 \mathrm{mg} / \mathrm{l}$, maka limbah tersebut dapat diolah dengan proses anaerob. Konsentrasi COD minimum untuk mencapai keberhasilan pengolahan anaerob adalah 1000 $\mathrm{mg} / \mathrm{l}$, sementara batas maksimum untuk pengolahan anaerob adalah $30000 \mathrm{mg} / \mathrm{l}$ [16].

\section{Karakteristik Kotoran Sapi sebagai Inokulum}

Pada penelitian ini inokulum yang digunakan adalah kotoran sapi yang telah diaklimatisasi selama 10 hari, berakhirnya proses aklimatisasi ditandai dengan terbentuknya biogas yang mengindikasikan bakteri sudah dapat beradaptasi.

Tabel 2. Karakteristik Inokulum Kotoran Sapi

\begin{tabular}{|c|c|c|c|}
\hline \multirow{2}{*}{ Parameter } & \multirow{2}{*}{ Satuan } & \multicolumn{2}{|c|}{ Teraklimatisasi } \\
\cline { 3 - 4 } & & $\begin{array}{c}\text { Asam } \\
\text { pH 5,5 }\end{array}$ & $\begin{array}{c}\text { Netral } \\
\text { pH 7 }\end{array}$ \\
\hline $\mathrm{TSS}$ & $\mathrm{mg} / \mathrm{L}$ & 5916,52 & 5686,52 \\
\hline $\mathrm{VSS}$ & $\mathrm{mg} / \mathrm{L}$ & 4437,38 & 4206,91 \\
\hline
\end{tabular}

Berdasarkan Tabel 2 dapat dilihat konsentrasi VSS yang diperoleh setelah aklimatisasi dalam suasana $\mathrm{pH}$ asam dan netral berturut-turut adalah 4437,38 mg/l dan 4206,91 mg/l. Konsentrasi VSS yang didapatkan dalam percobaan ini telah memenuhi syarat untuk pengolahan anaerobik yaitu, konsentrasi VSS lebih dari $4000 \mathrm{mg} / \mathrm{l}$ atau minimal 2000 - $4000 \mathrm{mg} / \mathrm{l}$ [1].

\section{Karakteristik Bahan Campuran}

Limbah cair tahu dicampur dengan inokulum sebanyak 20\% dari volume kerja yaitu 1,4 L. Adapun hasil uji karakteristik bahan campuran dapat dilihat pada Tabel 3.

.Tabel 3. Karakteristik Bahan Campuran

\begin{tabular}{|l|c|c|c|c|}
\hline \multirow{2}{*}{ Parameter } & \multirow{2}{*}{ Satuan } & \multirow{2}{*}{ R1 } & \multicolumn{2}{|c|}{ R2 } \\
\cline { 4 - 5 } & & & R2-1 & R2-2 \\
\hline COD & $\mathrm{mg} / \mathrm{l}$ & 2597,9 & 2614,5 & 2055,3 \\
\hline VSS & $\mathrm{mg} / \mathrm{l}$ & 967,41 & 1013,56 & 1605,4 \\
\hline pH & $\mathrm{mg} / \mathrm{l}$ & 7 & 5,5 & 7 \\
\hline
\end{tabular}

Keterangan:

R1 : Digester anerob satu tahap

R2 : Digester anaerob dua tahap

R2-1 : Digester anaerob dua tahap:tahap pertama

R2-2 : Digester anaerob dua tahap:tahap kedua

Berdasarkan Tabel 3 dapat dilihat bahwa pada $\mathrm{R} 1$ dan $\mathrm{R} 2$ dioperasikan dalam suasana $\mathrm{pH}$ yang berbeda. Pada bioreaktor anaerob satu tahap (R1) $\mathrm{pH}$ diatur dalam suasana netral. Sedangkan pada bioreaktor anaerobik dua tahap (R2), tahap pertama (R2-1) dimana terjadi proses asidifikasi dioperasikan selama dua hari dalam kondisi asam yaitu $\mathrm{pH} 5,5$, pada tahap kedua (R2-1) dimana terjadi proses metanogenesis $\mathrm{pH}$ diatur dalam suasana netral, yaitu $\mathrm{pH} 7$.

\section{Pengamatan Profil pH}

Faktor $\mathrm{pH}$ sangat berperan pada pengolahan anaerob karena pada rentang $\mathrm{pH}$ yang tidak sesuai, mikroba tidak dapat tumbuh dengan maksimum dan bahkan dapat menyebabkan kematian [13]. Hasil pengamatan $\mathrm{pH}$ selama proses pengolahan secara anaerob pada R1, R21, R2-2 dapat dilihat pada Gambar 2. 


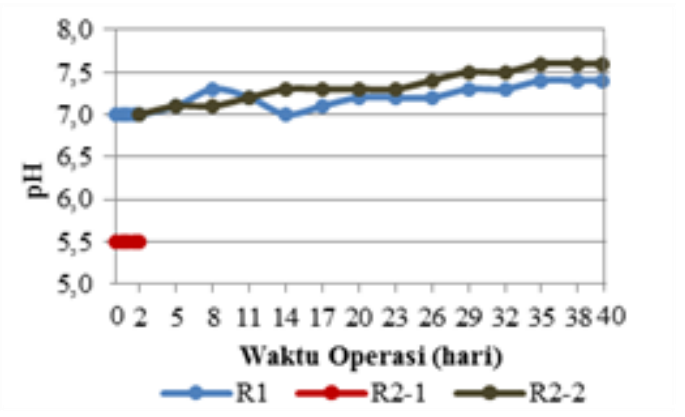

Gambar 2. Profil pH pada Bioreaktor Anaerobik Satu Tahap dan Dua Tahap

Berdasarkan Gambar 2 dapat dilihat bahwa perubahan $\mathrm{pH}$ selama proses pengolahan tidak signifikan. Pada R1 nilai $\mathrm{pH}$ cenderung mengalami kenaikan, dimana $\mathrm{pH}$ berada dalam rentang 7 - 7,4. Pada tahap ini nilai $\mathrm{pH}$ relatif meningkat, hal ini mengindikasikan terjadinya degradasi protein yang menghasilkan ammonium yang merupakan buffer alami. Penguraian senyawa organik terdapat pendegradasian protein menjadi ammonia nitrogen (NH3-N), kemudian bereaksi dengan air membentuk ammonium nitrogen (NH4-N) [4].

Derajat keasaman $(\mathrm{pH})$ pada $\mathrm{R} 2-1$ stabil diangka 5,5. Keadaan $\mathrm{pH}$ yang stabil pada R2-1 menunjukkan produksi VFA dan ammonium nitrogen (NH4-N) berkesinambungan dalam jumlah yang seimbang.

Profil $\mathrm{pH}$ pada $\mathrm{R} 2-2$ berada dalam rentang 7 - 7,6. Pengamatan pH pada R2-2 berlangsung selama 38 hari yang dimulai setelah $\mathrm{t}=48$ jam pada R2-1. Dari pengamatan $\mathrm{pH}$ pada R2-2 diketahui bahwa perubahan $\mathrm{pH}$ pada R2-2 sama dengan R1 yaitu cenderung mengalami kenaikan. Hal ini menunjukkan pada proses ini asam-asam organik dipecah, akibatnya $\mathrm{pH}$ campuran mengalami kenaikan.

Dalam penelitian ini, profil $\mathrm{pH}$ pada $\mathrm{R} 1, \mathrm{R} 2-$ 1, dan R2-2 menunjukkan bahwa $\mathrm{pH}$ pada masing-masing proses masih mendukung proses anaerobik pada R1, R2-1 dan R2-2. Nilai pH optimum untuk tahap pembentukan asam berada dalam kisaran 5,0-6,5 [9]. Sementara $\mathrm{pH}$ optimum untuk mikroba metanogensis berada dalam kisaran 6,4-7,8 [6]. Diluar rentang $\mathrm{pH}$ tersebut, penguraian tetap berjalan dengan efisiensi yang berkurang.

\section{Penyisihan Bahan Organik (COD)}

COD menunjukkan jumlah oksigen yang diperlukan agar bahan yang terdapat pada limbah cair dapat teroksidasi secara kimiawi, baik yang dapat didegradasi oleh mikroorganisme maupun yang sukar didegradasi. Hasil analisa COD pada R1, R2-1 dan R2-2 dapat dilihat pada Gambar 3.

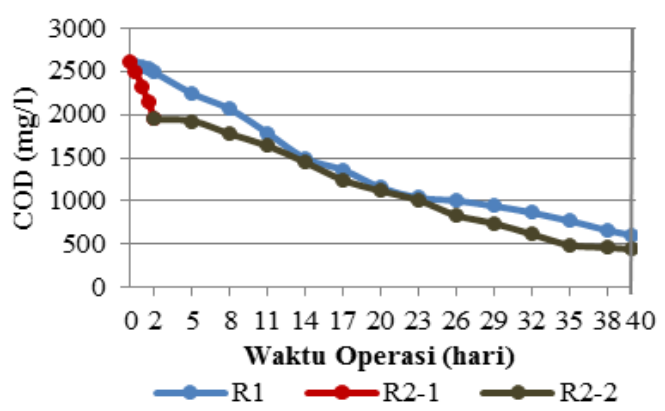

Gambar 3. Konsentrasi COD pada Bioreaktor Anaerobik Satu Tahap dan Dua Tahap

Dari Gambar 3 dapat dilihat konsentrasi awal COD pada R1 yaitu $2598 \mathrm{mg} / \mathrm{L}$, kemudian tereduksi sebesar $76,7 \%$ saat akhir pengolahan. Konsentrasi COD mengalami penurunan terbesar pada hari ke-14. Hal ini menunjukkan adanya aktivitas bakteri didalam pengolahan yang berfungsi mempercepat perombakan bahan organik, dimana secara tidak langsung juga dapat menurunkan nilai COD.

Konsentrasi COD pada R2-1 mengalami penurunan yang signifikan. Pada awal pengolahan konsentrasi COD adalah $2615 \mathrm{mg} / \mathrm{L}$, kemudian selama dua hari waktu operasi konsentrasi COD mengalami penurunan sebesar $25,6 \%$, dengan penurunan terbesar pada $\mathrm{t}=48$ jam. Penurunan konsentrasi COD yang signifikan $(\mathrm{P}>0.05)$ pada tahap $\mathrm{R} 2-1$ dimana terjadi proses asidifikasi ini menunjukkan proses hidrolisis berlangsung lebih cepat, hal ini disebabkan oleh sesuainya kondisi $\mathrm{pH}$ yang dibutuhkan bakteri pada tahap ini. Efisiensi penyisihan pada tahap asidogenik menunjukkan penurunan COD yang selalu lebih rendah dari $54 \%$ [15].

Proses pada R2-2 merupakan lanjutan dari R2-1. Pada R2-2 proses hidrolisis masih tetap berlangsung meskipun pada tahapan ini didominasi proses pembentukan metan. Pada tahap ini COD dianalisa setelah $\mathrm{t}=48$ jam pada R2-1 hingga hari ke-40. Konsentrasi COD pada akhir pengolahan R2-1 adalah $1945 \mathrm{mg} / \mathrm{l}$ kemudian ditambahkan inokulum kotoran sapi pada saat memasuki R2-2, hal ini menyebabkan konsentrasi awal COD pada R2-2 menjadi 2055 $\mathrm{mg} / \mathrm{l}$, kemudian pada hari ke-40 COD tereduksi sebesar $83,1 \%$.

\section{Pertumbuhan Mikroorganisme}

Pertumbuhan mikroorganisme di dalam bioreaktor diamati sebagai VSS yang merupakan konsentrasi padatan tersuspensi yang menguap pada suhu $\pm 550^{\circ} \mathrm{C}$. Pertumbuhan mikroorganisme pada R1, R2-1 dan R2-2 dapat dilihat pada Gambar 4. 


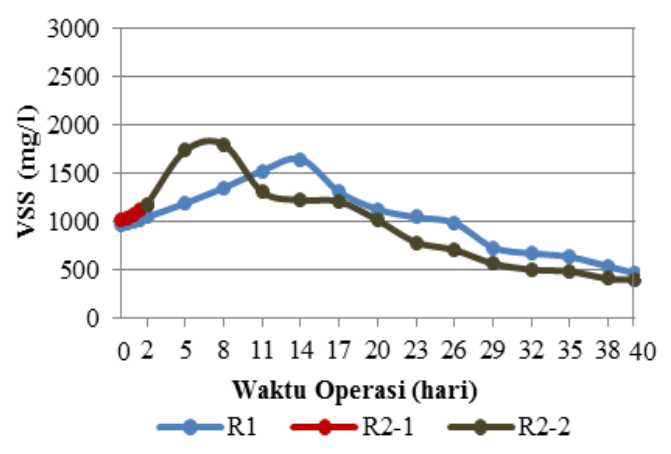

Gambar 4. Konsentrasi VSS pada Bioreaktor Anaerobik Satu Tahap dan Dua Tahap

Konsentrasi VSS pada awal pengolahan pada R1 sebagaimana yang ditunjukkan Gambar 4 adalah 967 mg/l. Pada hari ke-0 sampai hari ke2 masih memiliki pertumbuhan yang lambat (fase lag). Hal ini dapat disebabkan oleh tidak optimumnya suasana $\mathrm{pH}$ yang dibutuhkan oleh bakteri fermentatif. Akan tetapi pada hari ke-5 sudah mulai terjadi peningkatan pertumbuhan hingga mencapai pertumbuhan optimum (fase eksponensial) pada hari ke-14 dengan kadar VSS yaitu $1644 \mathrm{mg} / \mathrm{l}$. selanjutnya kadar VSS cenderung menurun hingga akhir pengolahan mencapai $468 \mathrm{mg} / \mathrm{l}$. Hasil ini menunjukkan bahwa semakin berkurang jumlah nutrisi, maka semakin menurun pula populasi bakteri.

Konsentrasi VSS pada R2-1 mengalamai kenaikan dan belum mengalami penurunan. Konsentrasi awal VSS yaitu sebesar 1014 mg/l, kemudian meningkat hingga $\mathrm{t}=48$ jam dengan konsentrasi VSS $1176 \mathrm{mg} / \mathrm{l}$. Bakteri yang tumbuh pada proses asidifikasi yang terjadi pada R2-1 adalah kelompok bakteri hidrolitik dan asidogenik dimana pertumbuhan bakteri pada tahap ini berlangsung lebih cepat dibandingkan bakteri metanogenik. Derajat keasaman $(\mathrm{pH})$ pada R2-1 mendukung laju pertumbuhan mikroba asidogenik. Nilai $\mathrm{pH}$ optimum untuk tahap asidifikasi pada proses anaerobik bekisar 5,0-6,5 [9].

Pada R2-2 kembali ditambahkan kotoran sapi yang telah diaklimatisasi dalam suasana netral (pH 7) sebanyak 1,4 ml. Konsentrasi awal VSS pada R2-2 adalah $1605 \mathrm{mg} / \mathrm{l}$, kemudian pada pengamatan hari ke-5 VSS kadar menjadi 1732 $\mathrm{mg} / \mathrm{l}$ dan terus meningkat mencapai pertumbuhan optimum (fase eksponsial) yaitu $1794 \mathrm{mg} / \mathrm{L}$ pada hari ke-8 dan mengalami penurunan pada hari ke-11 hingga konsentrasi VSS $394 \mathrm{mg} / \mathrm{l}$ pada hari ke-40. Penurunan konsentrasi populasi mikroba diakibatkan jumlah kebutuhan nutrisinya berkurang.

Di dalam reaktor anaerob terdapat dua jenis bakteri yang sangat berperan, yakni bakteri asidogenik dan bakteri metanogenik. Kedua jenis bakteri ini perlu seimbang. Bakteri-bakteri ini memanfaatkan bahan organik dan memproduksi metan dan gas lainnya dalam siklus hidupnya pada kondisi anaerob.

\section{Produksi VFA}

VFA merupakan asam organik berantai pendek (asam format, asam asetat, asam propinonat, asam butirat dan asam pentanoat) hasil dari proses asidifikasi. Terbentuknya VFA menjadi salah satu tanda bahwa proses asidogenesis berjalan dengan baik. Metode yang digunakan untuk analisa VFA adalah metode destilasi uap (steam destilation). Konsentrasi VFA hasil penelitian ini ditampilkan pada Gambar 5.

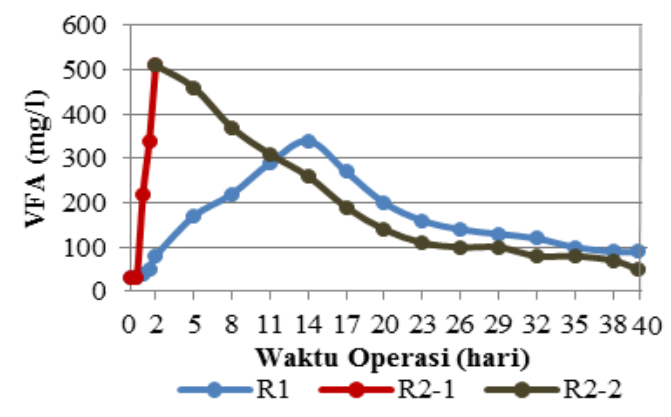

Gambar 5. Konsentrasi VFA pada Bioreaktor Anaerobik Satu Tahap dan Dua Tahap

Dari Gambar 5 dapat dilihat konsentrasi VFA pada awal proses pengolahan menggunakan bioreaktor anaerob satu tahap adalah $30 \mathrm{mg} / \mathrm{l}$. Konsentrasi VFA paling tinggi dihasilkan pada hari ke-14, yaitu $340 \mathrm{mg} / \mathrm{l}$. Hal ini mengindikasikan bahwa hingga hari ke-14 tahap ini didominasi oleh proses asidifikasi. Kemudian cenderung menurun hingga hari ke-40 konsentrasi VSS menjadi $90 \mathrm{mg} / \mathrm{l}$. Hal ini disebabkan oleh VFA yang dihasilkan mulai dikonversi menjadi $\mathrm{CH}_{4}$ dan $\mathrm{CO}_{2}$.

Konsentrasi awal VFA pada R2-1 sama dengan konsentrasi VFA pada R1yaitu $30 \mathrm{mg} / \mathrm{L}$. Nilai VFA mengalami kenaikan mulai dari $\mathrm{t}=12$ jam. Konsentrasi vss pada $\mathrm{t}=36$ jam adalah 220 mg/l dan kadar tertinggi dihasilkan pada $\mathrm{t}=48$ jam yaitu $510 \mathrm{mg} / \mathrm{l}$. Kadar VFA pada R2-1 meningkat sebesar $33 \%$ dari pengelolahan anaerob satu tahap.

Konsentrasi VFA pada R2-2 mulai diamati pada setelah 48 jam pada R2-1. Nilai VFA pada keluaran R2-1 yaitu $510 \mathrm{mg} / \mathrm{L}$, yang kemudian akan diuraikan oleh bakteri pembentuk metana menjadi gas metan $\left(\mathrm{CH}_{4}\right)$ dan kabon dioksida $\left(\mathrm{CO}_{2}\right)$. Hal tersebut menyebabkan konsentrasi VFA pada R2-2 
cenderung menurun hingga hari ke-40 dimana konsentrsai VFA sebanyak $50 \mathrm{mg} / \mathrm{l}$.

Dalam penelitian ini, produksi VFA yang dihasilkan pada R1 dan R2-1 masih mendukung proses pengolahan anaerob. Konsentrasi VFA > $2.000 \mathrm{mg} / \mathrm{l}$ menurunkan kinerja pada saat proses hidrolisis dan peruraian anaerobik dan menyebabkan kematikan pada mikroorganisme sehingga produksi biogas berkurang [14].

\section{Produksi Biogas}

Proses terakhir dari proses anaerobik adalah proses metanogenesis. Metanogenesis merupakan langkah penting dalam proses pengolahan anaerobik secara keseluruhan, karena proses ini adalah yang paling lambat pada proses reaksi biokimia, mengubah asam-asam volatil menjadi gas $\mathrm{CH}_{4}, \mathrm{CO}_{2}$, dan lain sebagainya [8]. Produksi harian biogas pada penelitian ini ditampilkan pada Gambar 6.

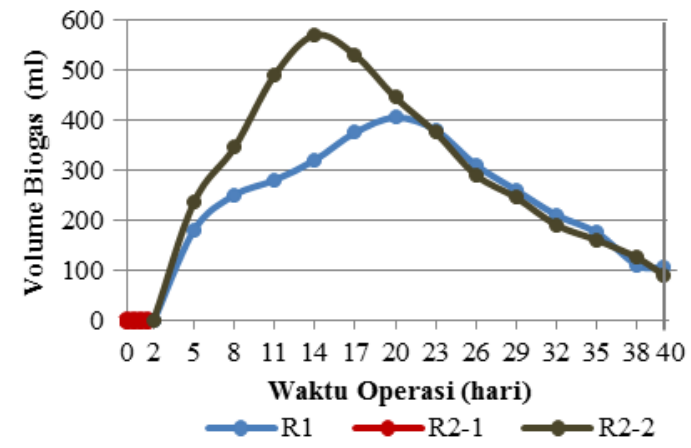

Gambar 6. Produksi Biogas pada Bioreaktor Anaerobik Satu Tahap dan Dua Tahap.

Sebagaimana yang ditampilkan pada Gambar 6 dimulai setelah hari ke-2. Volume harian biogas tertinggi pada hari ke-20 yaitu 405 $\mathrm{ml}$ dan pada hari ke-40 volume biogas sebesar $105 \mathrm{ml}$. Volume kumulatif biogas selama 40 hari pada R1 adalah $3360 \mathrm{ml}$.

Pada R2-1 tidak terdapat biogas yang dihasilkan selama 2 hari. Hal ini menunjukkan pada tahap ini hanya berlangsung pembentukan asam dan tahap metanogenesis belum berlangsung.

Setelah 2 hari belangsung proses asidifikasi maka dilanjutkan dengan proses metanogenesis pada R2-2, dimana menghasilkan biogas. Volume biogas tertinggi pada hari ke-14, yaitu $570 \mathrm{ml}$, dan pada hari ke-40 volume biogas sebesar $90 \mathrm{ml}$. Volume kumulatif biogas selama 40 hari pada R2-2 adalah $4091 \mathrm{ml}$. Adapun penurunan volume biogas yang terjadi pada bioreaktor disebabkan oleh kandungan bahan organik tinggal sedikit yang ditandai dengan nilai COD yang rendah.
Dari volume kumulatif biogas dapat diketahui yield biogas, yaitu dengan membagi volume kumulatif biogas dengan konsentrasi COD yang terkonversi, maka didapatkan hasil yield biogas pada R1 dan R2 masing-masing yaitu $0,24 \mathrm{~L} / \mathrm{g} \mathrm{COD}_{\text {terkonversi }}$ dan $0,27 \mathrm{~L} / \mathrm{g}$ $\mathrm{COD}_{\text {terkonversi. }}$

\section{Kesimpulan}

Adanya pengaruh pengolahan anaerob satu tahap dan dua tahap terhadap kinerja bioreaktor dalam pengolahan limbah cair tahu yang dilihat dari efisiensi penyisihan COD, laju pertumbuhan bakteri (VSS), produksi VFA, dan produksi biogas. Efisiensi penyisihan COD pada bioreaktor anaerob satu tahap adalah $76,7 \%$ dan meningkat $6,8 \%$ pada bioreaktor anaerob dua tahap. Laju pertumbuhan mikroorganisme pada bioreaktor dua tahap lebih cepat yaitu mencapai pertumbuhan optimum pada hari ke- 8 dan pada bioreaktor dua tahap bakteri mencapai pertumbuhan optimum pada hari ke-14. Produksi VFA pada pengolahan anaerob dua tahap meningkat signifikan sebesar $33 \%$ dari pengelolahan anaerob satu tahap. Yield biogas

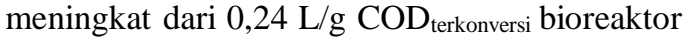
anaerob satu tahap menjadi $0,27 \mathrm{~L} / \mathrm{g}$ $\mathrm{COD}_{\text {terkonversi }}$ bioreaktor anaerob dua tahap.

\section{Daftar Pustaka}

[1] A. Syahrin, A. Andrio, N. Veronika, Proses Seeding Aklimatisasi untuk Pengolahan Anaerob Limbah Cair Produksi Minyak Sawit, Jurnal Teknik Lingkungan Universitas Riau, 3, (2016) 1-5.

[2] B. Demirel and O. Yenigun, Two-phase anaerobic digestion process: a review. Jounal of Chemical Technology and Biotechnology, 77, (2002) 743-755.

[3] H. J. Gijzen, Anaerobic Digestion of Cellulostic Waste by Rumen-Derived Process, Den Haag: Koninklijke Bibliotheek, 1987, p.12-16.

[4] I. Syaichurrozi dan Rusdi, Pencernaan Campuran Limbah Vinasse dan Limbah Cair Tahu untuk Meningkatkan Produksi Biogas. Jurnal Teknik Kimia. Universitas Sultan Agung Tirtayasa, Cilegon. 12, (2015) 23-28.

[5] Indriyati, Pengolahan Limbah Cir Organik secara Biologi Menggunakan Reaktor Anaerobik Lekat Diam, Pusat Pengkajian dan Penerapan Teknologi Lingkungan BPPT, 1, (2005) 330-340.

[6] M. Madyanova, Pengolahan Senyawa organik Limbah Cair Domestik Dengan Menggunakan Anaerobic Baffled Reactor 
(ABR), Teknik Lingkungan Insitute Teknologi Bandung, 2005, p.45-46.

[7] M. A. Kholiq. Perbandingan Sistem Digester Anaerob Termofilik Satu dan Dua Fase. Jurnal Teknologi Lingkungan, 8, (2007) 4347.

[8] M. L. Shuler, F. Kargi, Bioprocess Engineering, Prentice Hall Professional Technical Reference, 2002, p.174-175.

[9] Malina and Pohland, Desaign of Anaerobic Prosesses for The Treatment of Industrial and Municipal Wastes, Technomic Publishing Co, Lancaster, Pennsylvania, 1992, p.79.

[10] P. Iriani, Y. Suprianti, F. Yulistiani, Fermentasi Anaerobik Biogas Dua Tahap dengan Aklimatisasi dan Pengkondisian $\mathrm{pH}$ Fermentasi, Jurnal Teknik Kimia dan Lingkungan, 1, (2017) 1-10.

[11] S. Moertinah, Kajian Proses Anaerobik Sebagai Alternatif Teknologi Pengolahan Air Limbah Industri Organik Tinggi, Jurnal Riset TPPI, 1, (2010) $104-114$.

[12]S. E. Nayono, Anaerobic digestion of organic solid waste for energy production, KIT Scientific Publishing Karlsruhe, 2009, p.21.

[13] S. Simamora, Salundik, S. Wahyuni, Surajudin, Membuat Biogas Pengganti Bahan Bakar Minyak dan Gas dari Feses, Agromedia Pustaka, Jakarta, 2006, p.45.

[14] U. Wiesmann, Choi, I. S. Choi, E. M. Dombrowski, Fundamental Biological Wastewater Treatment, Wiley-VchVerlag Gmbh and Co. Kgaa,Berlin, 2007, p.93-94.

[15] V. Blonskaja, Use of Two Stage Anaerobic Treatment for Distillery Waste, Journal Elsevier Science, 7, (2002) 671-678.

[16] W. W. Eckenfelder, J. Patocka, A. T. Watkin, Wastewater Treatment,Chemical Engineering, 1995, p.142. 